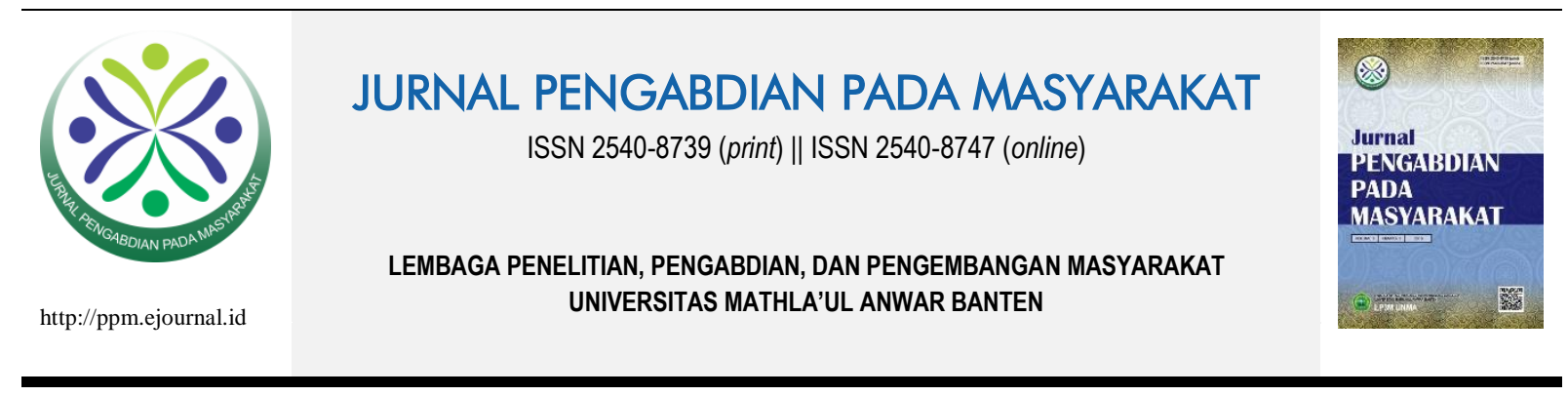

EDITORIAL

\title{
Pemberdayaan Masyarakat Berbasis Kebudayaan
}

\author{
Aprinus Salam \\ Kepala Pusat Studi Kebudayaan Universitas Gadjah Mada
}

\begin{abstract}
Pemberdayaan adalah satu usaha/program/kegiatan untuk memampukan seseorang/masyarakat, dari tidak/belum bisa menjadi bisa, dari tidak/belum terampil menjadi terampil, dari tidak/kurang terdidik menjadi terdidik, dari tidak/belum tahu menjadi tahu, dan seterusnya. Pemberdayaan harus tepat guna dan sesuai dengan kebutuhan masyarakat bersangkutan.
\end{abstract}

Masyarakat adalah sekumpulan orang/manusia yang terikat dalam satu aturan dan norma tertentu. Dalam masyarakat terdapat laki-laki dan perempuan (mungkin juga di antaranya), terdapat strata usia, terdapat perbedaan agama, terdapat orang yang kaya/mampu, menengah, dan tidak mampu/miskin, terdapat mereka yang kurang terdidik dan yang terdidik, terdapat perbedaan suku, terdapat partai politik yang berbeda, terdapat kebiasaan dan cita-cita yang berbeda, dan sebagainya.

Pada tingkat masyarakat, pemberdayaan masyarakat adalah memampukan atau meningkatkan kinerja masyarakat dalam mengelola dirinya menuju masa depan yang lebih baik/berkemampuan. Pada tataran ini, yang dibicarakan adalah institusi-institusi dalam masyarakat, seperti institusi swasta, pemerintah daerah, komunitas-komunitas profesi, satuan RT, RW, kelurahan, lembaga pendidikan, Ormas dan Orsospol, dan sebagainya.

Kebudayaan adalah cara berpikir manusia/masyarakat dan dalam cara itu melakukan berbagai praktik kehidupan, praktik bekerja, praktik beragama dengan ritual-ritualnnya, praktik pendidikan, praktik berpolitik, dan berbagai praktik sehari-hari lainnya. Terdapat dialektika di dalamnya, yakni ketika cara berpikir "dikonstruksi" oleh agama, pendidikan, mitos-mitos, dan berbagai wacana yang ditemui dan dipelajari seseorang dalam hidupnya.

Itulah sebabnya, dalam praktiknya, cara berpikir seseorang tidak sama. Tergantung pendidikan, tergantung sejarah hidup dan pengalamannya, tergantung posisi sosial ekonominya, tergantung agamanya, tergantung haluan politiknya, tergantung lingkungannya.

Namun, secara umum kebudayaan punya tujuan atau semacam misi. Sebaiknya, misi kebudayaan dirumuskan tergantung kepentingan dan kebutuhan daerahnya masingmasing. Hal itu dikarenakan kondisi setiap daerah juga berbeda-beda. Misi kebudayaan

${ }^{1}$ Corresponding author: Departemen Bahasa dan Sastra, FIB UGM. Email: aprinus@ugm.ac.id; aprinussalam@gmail.com. 
negara Indonesia terdapat dalam pembukaan UUD 1945 dan Pancasila, yakni terwujudnya masyarakat adil dan makmur. Untuk tujuan masyarakat adil dan makmur, kita bolehlah "mendompleng" negara.

Tetapi, rezeki ekonomi, rezeki pekerjaan, rezeki pendidikan, itu tidak bisa dipaksakan. Fasilitas-fasilitas untuk itu juga akan sangat terbatas. Yang bisa diupayakan adalah situasinya, terdapat rasa keadilan di dalamnya. Maka, saya usul, untuk daerah misi kebudayaannya adalah bagaimana setiap orang (dalam keragamannya) mendapatkan situasi nyaman untuk melakukan mobilitas sosial dalam melakukan praktik kehidupan. Orang merasa nyaman walau ada perbedaan ekonomi, agama, pendidikan, rezeki dan sebagainya. Kenapa kenyamanan itu penting, karena warga masyarakat akan sulit menjadi kaya semuanya, akan sulit untuk terdidik semuanya, akan sulit hidup dalam agama yang sama, tidak mungkin juga hidup dalam politik yang sama. Itulah hukum alam, itulah sunatullah, selalu akan ada perbedaan dan keragaman.

Kata kuncinya adalah memberi kesempatan yang luas dan situasi nyaman agar masyarakat dengan leluasa melakukan mobilitas sosial dalam menjalankan hidupnya. Kenyamanan akan didapatkan jika terdapat kebijakan dan sikap-sikap empatik dan simpatik dalam melakukan berbagai program pemberdayaan, yang berorientasi pada keberpihakan. Kenyamanan juga akan didapatkan jika indeks kesenjangan tidak terlalu menyolok.

Kembali ke persoalan pemberdayaan-masyarakat. Apakah pemberdayaan dimaksudkan untuk memampukan semua orang. Iya. Ada dua level pemberdayaan yang berbeda. Pertama, pemberdayaan yang memampukan mereka yang tidak/kurang/belum terdidik, mereka yang tidak/kurang/belum memiliki keterampilan untuk kebutuhan hidupnya, mereka yang tidak/kurang/belum baik ekonominya dengan kriteria yang mapan. Kriteria ini penting dan ada rumusnya.

Persoalannya, kadang kita tidak memiliki data yang akurat. Ini masalahnya. Di sini pula dibutuhkan riset yang memadai dan mendalam. Sangat mungkin program KKN PPM dapat dijadikan model dalam mendapatkan data yang dibutuhkan Pemda dalam mendata kebutuhan untuk mendapatkan data yang akurat.

Daerah harus punya data yang akurat tentang mereka yang tidak/kurang/belum ini. Sebetulnya, permberdayaan masyarakat harus fokus ke mereka, dengan berbagai program yang sesuai dan relevan dengan kebudayaan. Jadi, mereka yang sudah mampu, ekonominya baik, terdidik, tidak masuk dalam strategi permberdayaan ini. Jika ternyata, sebagai misal, data mereka yang tidak/kurang/belum mampu itu sekitar $45 \%$, maka program pemberdayaan cuma menangani $45 \%$ penduduk.

Pemerintah daerah juga harus punya data yang akurat terhadap karakter yang tidak/kurang/belum mampu tersebut, dan relevansi antara tidak/kurang/belum mampu ekonomi, pendidikan, atau keterampilan. Untuk satu sub-unit masyarakat tertentu, mana yang lebih dominan. Keakurasian data menentukan program pemberdayaan apa yang relevan bagi sub-unit masyarakat tersebut.

Pemberdayaan apa yang perlu dimampukan kepada mereka yang sudah mampu ekonomi, pendidikan, atau yang sudah memiliki keterampilan tinggi (dalam berbagai bidangnya). Mereka diberdayakan untuk membantu saudara-saudaranya yang tidak/kurang/belum mampu tersebut. Dengan berbagai program yang relevan, mereka yang telah mampu harus diberi kesempatan untuk "dipertemukan" dalam berbagai "ruang publik", untuk membantu memberdayakan mereka yang tidak/kurang/belum mampu tersebut. 
Apa kendalanya?

1. Secara umum masyarakat di manapun sekarang ini cenderung individualis (sebagai salah satu ciri-ciri masyarakat modern). Ini terkakit dengan nilai-nilai budaya kegotongroyongan (nilai budaya tradisional) semakin terkikis.

2. Kantong-kantong sub-unit masyarakat yang tidak/kurang/belum mampu sangat tersebar hingga ke pelosok-pelosok yang sulit dijangkau.

3. Adanya kenyataan cara berpikir yang berbeda-beda terhadap kehidupan.

4. Kurangnya "ruang publik" yang mempertemukan perbedaan dan keragaman.

5. Penduduk terus bertambah, lahan tidak bertambah.

6. Kuatnya kapitalisme mencengkram masyarakat, sehingga segala sesuatunya dihitung berdasarkan untung dan rugi ekonomi. (Tapi ini juga kebudayaan, dan kebudayaan seperti inilah yang sekarang dominan).

7. Meningkatnya konsumtivisme.

8. Semakin banyaknya gejala intoleransi, dan sebagainya.

Adakah kelebihan?

1. Potensi tersembunyi dalam satu sub-unit masyarakat, seperti potensi kesenian, keterampilan lokal, yang bisa dijadikan "ruang publik" pemberdayaan.

2. Potensi alam, potensi pertanian, dan sebagainya.

3. Potensi pengetahuan dan kearifan lokal, sebagai penyeimbang modernisme dan kapitalisme.

4. Berbagai keunikan lainnya yang layak diaktualkan kembali.

Beberapa keuntungan dan kemudahan

1. Teknologi komunikasi yang sangat membantu dan dapat diberdayakan secara maksimal.

2. Dorongan kesamaan semangat dan kerja sama dengan berbagai daerah lain.

3. Adanya gejala peningkatan daya beli (bukan dalam pengertian konsumtif) dan produksi masyarakat.

4. Meningkatnya ilmu dan pengetahuan yang semakin filantropis.

Beberapa tawaran solusi

1. Mempermudah masyarakat dalam segala level dan perbedaannya untuk mengakses mobilitas sosial.

2. Memperbanyak "ruang-ruang publik" dengan konsep kewisataan.

3. Mekanisme tutorial dan sukarelawan untuk advokasi dan pendampingan yang menjadi sasaran pemberdayaan dengan konsep multiplier effect.

4. Mengefektifkan manajemen birokrasi, dan transparansi. 